\title{
鼻副鼻腔内に発生した䯣外性形質細胞腫例
}

\author{
金井 健吾 ${ }^{1,2)}$, 檜垣 貴哉 ${ }^{2)}$, 平田 裕二 ${ }^{1)}$, \\ 藤原 瑠美 $^{1)}$, 山本まり恵 ${ }^{2}$, 假谷 伸 ${ }^{2)}$, \\ 岡野 光博 ${ }^{3)}$ \\ 1)香川県立中央病院耳鼻咽喉科・頭頸部外科 \\ ${ }^{2)}$ 岡山大学大学院医歯薬学総合研究科耳鼻咽喉·頭頸部外科 \\ ${ }^{3}$ 国際医療福祉大学耳鼻咽喉科·頭頸部外科
}

形質細胞腫瘍は, B細胞の最終分化形態である形質細胞がモノクローナル性に増殖し, 骨または䯣外組織に 局所的に発生する腫瘍性疾患である。髄外性形質細胞腫は骨䯣以外の組織に発生する形質細胞腫で, 頭頸部領 域に好発することが知られており耳鼻咽诶科医として念頭に置くべき疾患の1つと思われる。症例は83歳男性。 主訴は左鼻出血・左鼻閉。半年前からの反復する左鼻出血・左鼻閉で近医を受診し, 左鼻腔に腫瘤を認め当院

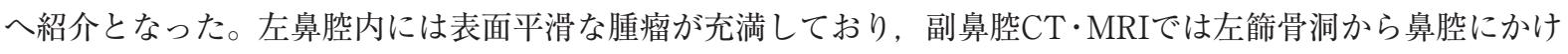
て占拠性病変を認めた。左鼻垫腫瘤の生検結果は炎症性変化の疑いとの診断であった。左鼻閉改善の希望があ り, 局所麻酔下で左鼻茸摘出術を施行し, 病理組織検査は形質細胞腫瘍であった。血中M蛋白や尿中BenceJones蛋白は陰性, 骨䯣生検は正常で骨髄腫の所見は認めず, 髄外性形質細胞腫の診断となった。FDG-PETで は左鼻副鼻沿内のみにFDG集積を認め, 頸部リンパ節転移や遠隔転移は認めなかった。全身麻酔下で左内視鏡 下鼻副鼻胿手術を施行した。腫瘍の周囲組織への浸潤は認めず肉眼的には完全摘出したが, 安全域をとってい ないため, 術後放射線治療を追加した（total $46 \mathrm{~Gy} / 23 \mathrm{fr}$ )。その後は再発なく外来にて経過観察中である。䯣 外性形質細胞腫は数年以上経過した後に多発性骨䯣腫へ移行することが報告されており, 局所再発や遠隔転移 の有無も含めて長期にわたり厳重な経過観察が必要と思われる。

キーワード：髄外性形質細胞腫，多発性骨䯣腫，鼻副鼻腔腫瘍，内視鏡下鼻副鼻胿手術，放射線治療

\section{A Case of Extraosseous Plasmacytoma that Developed in the Sinonasal Cavity}

\author{
Kengo Kanai ${ }^{1,2)}$, Takaya Higaki ${ }^{2)}$, Yuji Hirata ${ }^{1)}$, Rumi Fujiwara ${ }^{1)}$, \\ Marie Yamamoto ${ }^{2)}$, Shin Kariya ${ }^{2)}$, Mitsuhiro Okano ${ }^{3)}$
}

${ }^{1)}$ Department of Otoralyngology Head and Neck Surgery, Kagawa Prefectual Central Hospital

${ }^{2}$ Department of Otoralyngology Head and Neck Surgery,

Okayama University Graduate School of Medicine, Dentistry and Pharmaceutical Sciences

${ }^{3}$ Department of Otoralyngology Head and Neck Surgery, International University of Health and Welfare

Extraosseous plasmacytomas are localized plasma cell neoplasms that arise in tissues other than bone, and are most commonly located in the head and neck. The patient was a 83-year-old man who complained of left 
nasal bleeding and left nasal obstruction. He consulted a nearby doctor and a left nasal mass was discovered. A tumor with a smooth surface filled the left nasal cavity, and was observed from the left nasal cavity to the ethmoid sinus on sinus computed tomography (CT) and magnetic resonance imaging (MRI). Left nasal polypotomy under local anesthesia was performed for improvement of left nasal obstruction. A pathological examination revealed plasma cell neoplasms. However, blood M protein and urinary Bence-Jones protein were not present, and the bone marrow was found to be normal by biopsy; thus, findings of myeloma were not observed. The patient was diagnosed with extraosseous plasmacytoma and underwent left endoscopic sinus surgery under general anesthesia. The tumor had not infiltrated the surrounding tissues and was completely removed under visual inspection. However, the safety margin was not secured, which led to addition of radiotherapy after surgery. There has been no recurrence in two and a half years postoperatively. Since extraosseous plasmacytoma may shift to multiple myeloma after several years, there is a need to follow-up the patient regularly and carefully over a long period to monitor possible local recurrence and distant metastasis.

Key words : Extraosseous plasmacytoma, Multiple myeloma, Sinonasal mass, Endoscopic sinus surgery, Radiotherapy (2020年9月 8 日受稿, 2021 年 1 月 29 日受理)

\section{はじめに}

形質細胞腫瘍は, B細胞の最終分化形態である形質細 胞がモノクローナル性に増殖し，骨または髄外組織に局 所的に発生する腫瘍性疾患である ${ }^{1 \sim 4)}$ 。髄外性形質細胞腫 は骨髄以外の組織に発生する形質細胞腫瘍で ${ }^{5)}$, その約 70〜80\%が頭頸部領域に発生するとされており ${ }^{1,2,6 \sim 9)}$, 耳 鼻咽喉科医として念頭に置くべき疾患の1つと思われる。 今回我々は, 鼻副鼻腔内に発生した髄外性形質細胞腫例 の一例を経験したので報告する。

\section{症例}

83 歳 男性

主訴：左鼻出血, 左鼻閉

既往歴: 2 型糖尿病, 高血圧症, 脂質異常症, ラクナ 梗塞, 膀胱癌 (74歳で経尿道的手術)

内服薬：グリメピリド，シタグリプチンリン酸塩水和 物, ミグリトール，イプラグリフロジンL-プロリン，ポ リエンホスファチジルコリン, ベニジピン塩酸塩, フェ ノフィブラート, クロピドグレル

現病歴：半年前からの反復する左鼻出血と左鼻閉を自 覚し近医耳鼻咽喉科を受診したところ, 左鼻腔に腫瘤を 認めたため, $20 X X$ 年 2 月に精查加療目的で当科紹介と なった。

現症 : 左鼻腔内に腫瘤が充満しており, 腫瘤先端部は 軽度発赤があり後方は表面平滑であった（図 1$)$ 。

検査所見: 血液検査では, WBC 5100/ $\mu$ l (好中球 $66.9 \%$, リンパ球 $24.8 \%$, 単球 $5.3 \%$, 好酸球 $2.6 \%$, 好塩基球 $0.4 \%$ ), Hb 15.4 g/dl, Plt $15.2 \times 10^{4} / \mu \mathrm{l}$, TP 7.9 g/dL, Alb $4.3 \mathrm{~g} /$
dL, BUN 13.4 mg/dL, Cr 0.89 mg/dL, Na 135.6 mEq/ L, K $4.5 \mathrm{mEq} / \mathrm{L}, \quad$ Cl $102.4 \mathrm{mEq} / \mathrm{L}$, Ca $9.1 \mathrm{mg} / \mathrm{dl}$, CRP $0.60 \mathrm{mg} / \mathrm{dL}$, LDH $196 \mathrm{U} / \mathrm{L}$, Glu $336 \mathrm{mg} / \mathrm{dL}$, HbAlc $10.6 \%$ と糖尿病はコントロール不良であった。初診時の 単純CT（図2），単純・造影MRI（図3）では，左篩骨洞 から鼻腔に充満する $20 \times 30 \times 45 \mathrm{~mm}$ 大の占拠性病変を 認めたが，頭蓋底や眼窩への浸潤は認めず，骨破壊も認 めなかった。また, 左上顎洞は炎症性変化が疑われ, 頸 部リンパ節腫脹は認めなかった。内反性乳頭腫, 扁平上 皮癌などの悪性腫瘍, 肉芽腫性病変などの可能性を考え, 初診時に左鼻腔腫瘤を局所麻酔下で生検したところ，炎 症性変化の疑いとの結果であった。

経過：血糖コントロール不良のため, まずはかかり つけ内科で血糖コントロールを施行した。その後も左鼻 閉改善希望が強く, 血糖コントロールの後に（術前 $\mathrm{Glu}$ $96 \mathrm{mg} / \mathrm{dl}, \mathrm{HbAlc} 7.4 \%$ ), 初診時から3ヶ月後の $20 \mathrm{XX}$ 年 5 月に内視鏡下に左鼻茸切除術を施行した（手術時間 ;

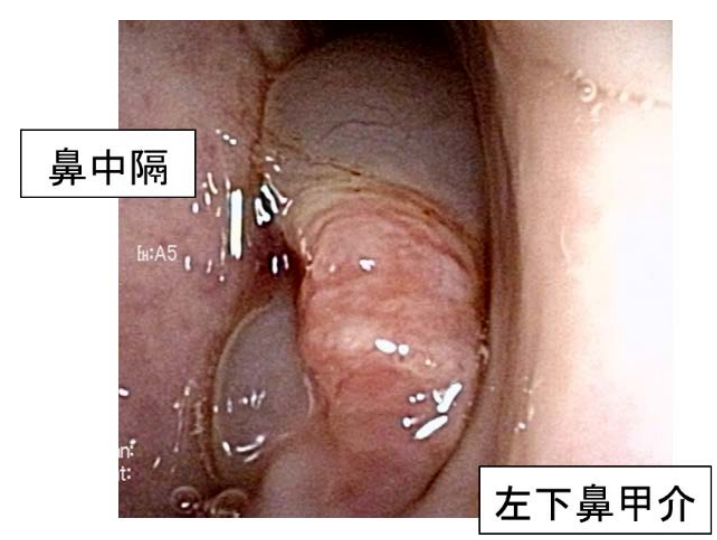

図1 左鼻腔所見 

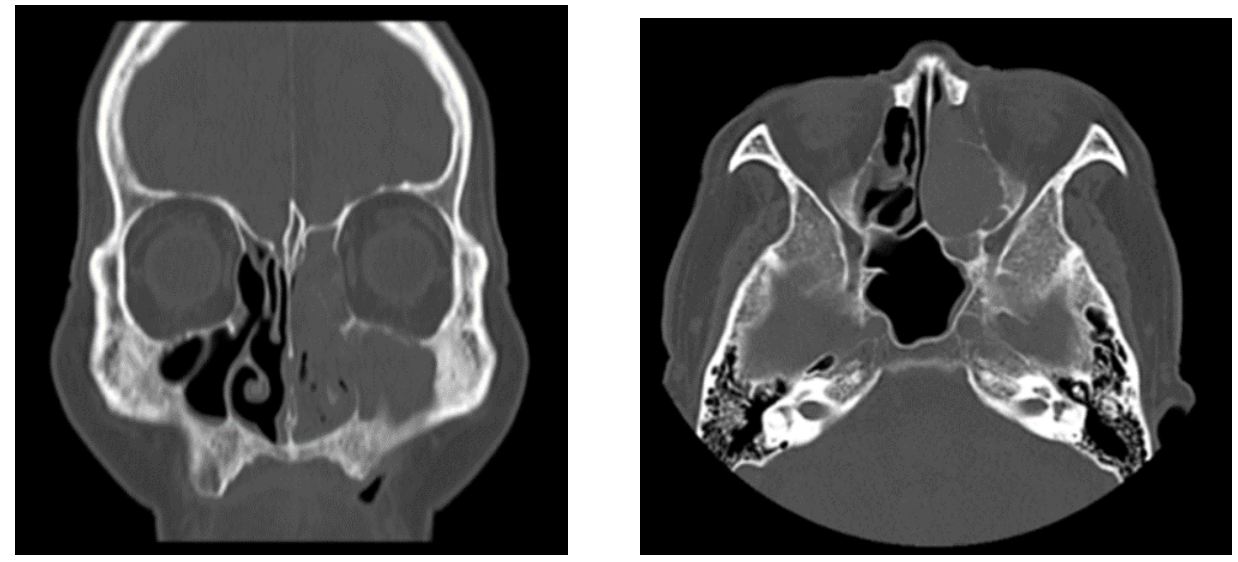

図2 初診時単純CT

（脂肪抑制 T1 強調ガドリニウム造影画像）
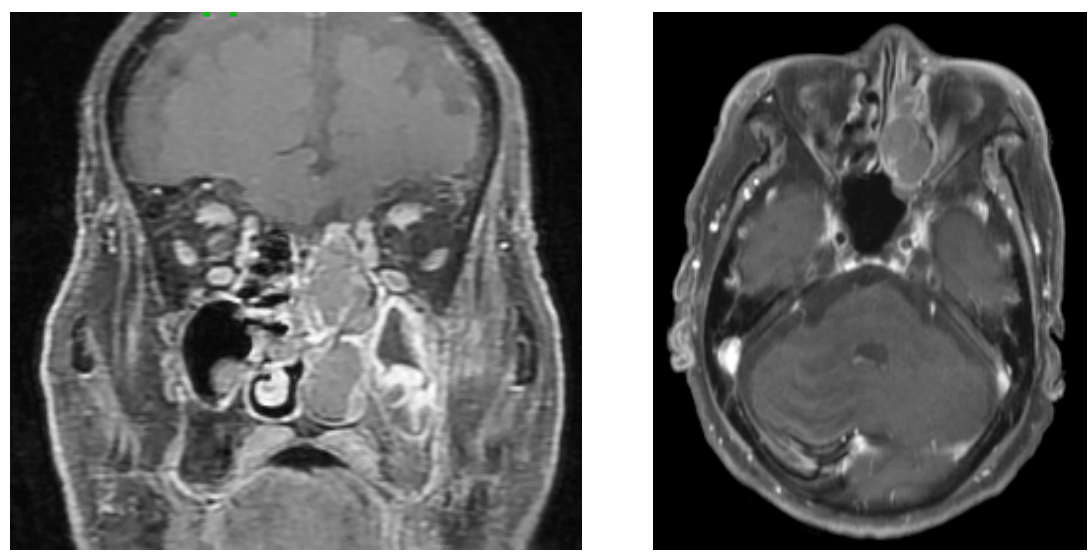

（脂肪抑制 T2 強調画像）
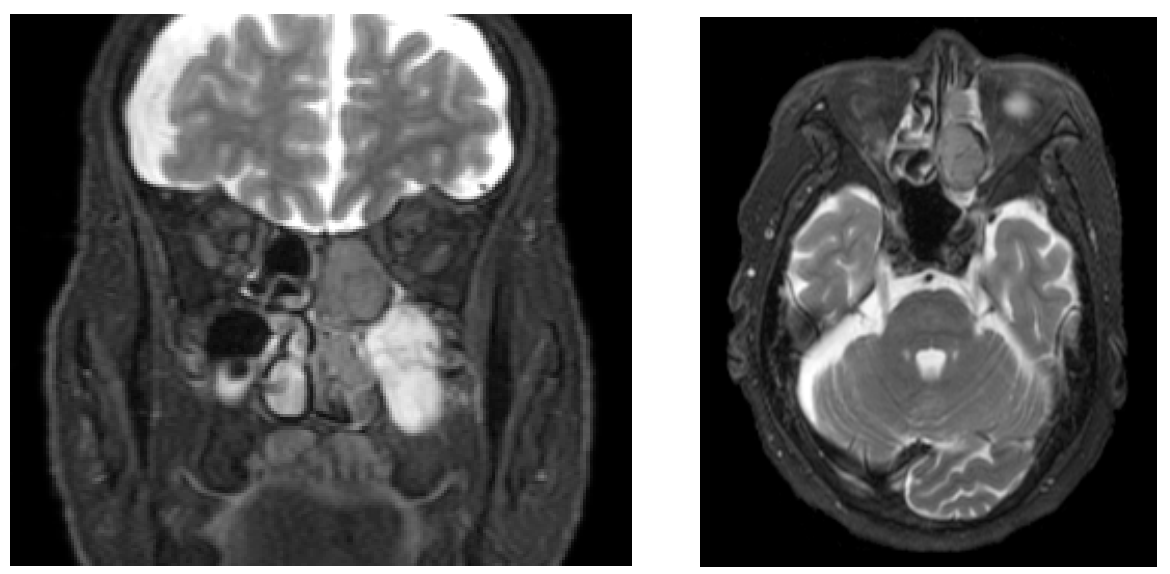

図3 初診時MRI

50 分, 出血量 ; 少量)。なお外来通院での治療を希望さ れたため局所麻酔下で施行した。左鼻腔腫瘤は左総鼻道 に充満しており，基部は左中鼻道に認めた。左総鼻道内 の腫瘤を切除し, 病理組織検査に提出した。

病理組織所見として, HE染色では, 異型細胞がびまん
性に増殖しており，3極分裂などの異常核分裂像を認め た（図4A）。免疫染色ではIgG陽性細胞を認め（図4B）, ISH (in situ hybridization) でК monotypeを認めた（図 4C)。以上から, IgG-א型の形質細胞腫瘍（Plasma cell neoplasm）の診断となった。 
当院血液内科に紹介し，多発性骨髄腫の合併の有無な どについて精查した。血液検査で, IgG $1732 \mathrm{mg} / \mathrm{dl}$, IgA $354 \mathrm{mg} / \mathrm{dl}, \quad I g M 78 \mathrm{mg} / \mathrm{dl}$ はいずれも正常範囲内で, 蛋 白分画（アルブミン, $\alpha 1$-globulin, $\alpha 2$-globulin, $\beta$-globulin, $\gamma$-globulin）も正常範囲内であった。血中M蛋白・尿中 Bence-Jones蛋白ともに陰性, 骨髄検査は正常で骨髄腫の 所見は認めなかった。FDG-PET (fluorodeoxy glucosepositron emission tomography）では, 左鼻副鼻腔内に SUVmax 10.74のFDG集積を認めたが，頸部リンパ節転 移や遠隔転移は認めなかった（図5)。以上から䯣外性形 質細胞腫の診断となった。

画像上，腫瘍は鼻副鼻胿内に限局し周团への浸潤を認 めず，切除可能と判断し 20XX年 7 月に全身麻酔下で左 内視鏡下鼻副鼻腔手術を施行した（手術時間；1時間 10 分, 出血量;少量)。腫瘍は左眼窩内側壁を基部として左 穊骨洞内に限局しており，腫瘍基部の粘膜を合併切除し たところ粘膜は容易に剥離でき，眼窩内側壁の骨を含め た周囲組織への腫瘍浸潤は認めず，眼窝内側壁の骨は温 存した。また，左上顎洞自然口を開放したところ膿汁 が排出され，左上顎洞は2次性の副鼻腔炎を呈していた。 摘出腫瘍は $15 \times 21 \times 25 \mathrm{~mm}$ 大で，腫瘍基部の正常粘膜 を含めて肉眼的には完全摘出できたが安全域をとってい ないため, 術後 3 週間後（20XX年 8 月）より, 強度変調 放射線治療 (Intensity Modulated Radiation Therapy; IMRT) で術後照射（2 Gy/fr, 23 fr, total 46 Gy）を施行 した（図6）。その後は約 2 年半を経過するが再発所見は 認めず，外来にて経過観察中である。

\section{考察}

形質細胞腫瘍は，B細胞の最終分化形態である形質細 胞がモノクローナル性に増殖し，骨または髄外組織に局 所的に発生する腫瘍性疾患 ${ }^{1 \sim 4)}$ と定義され，非IgM型意義 不明の単クローン性ガンマグロブリン血症, 形質細胞骨 髄腫, 形質細胞腫, 単クローン性免疫グロブリン沈着症, 腫瘍随伴症候群を伴う形質細胞腫瘍に分類され，さらに 形質細胞腫は骨の孤立性形質細胞腫と骨髄以外の組織に

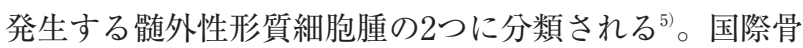
髄腫作業部会 (International Myeloma Working Group; IMWG）による，髄外性形質細胞腫の診断基準では，(1) 生検にてクローナルな形質細胞からなる軟部組織の形質 細胞腫の存在，(2)骨髄中にクローナルな形質細胞を認め ない，(3)骨X線，椎体および骨盤MRI（またはCT）で異 常を認めない, (4)臟器障害（高カルシウム血症, 腎不全, 貧血，骨病変）を認めない，の4項目すべて満たす疾患 と定義されている ${ }^{10)}$ 。特徵として, 男女比で約 $3: 1$ と男
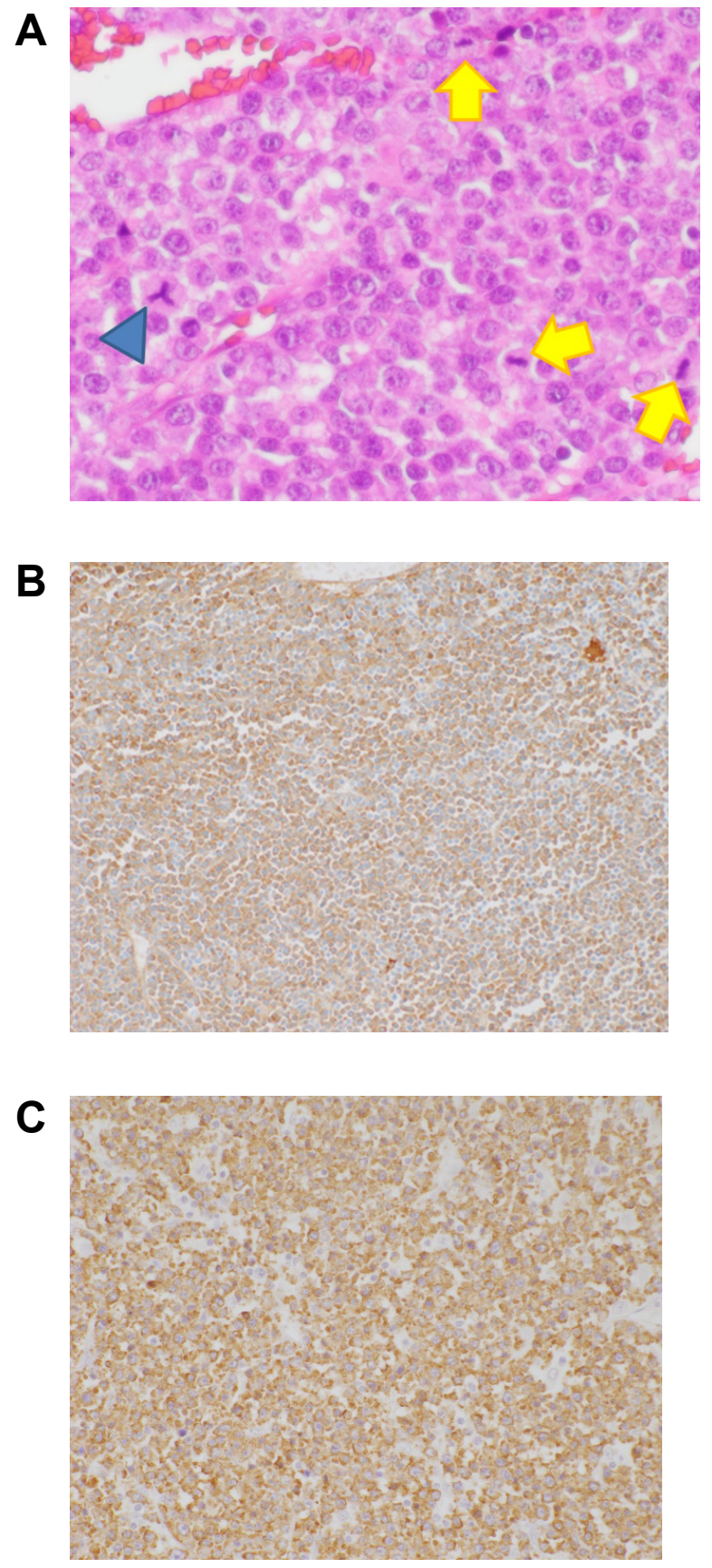

図4 A：HE染色（400倍視野）

HE染色では，異型細胞がびまん性に増殖しており， 3 極分裂などの異常核分裂像を認めた（矢印；核分裂 像，矢頭； 3 極分裂像)。

B : 免疫染色 $(400$ 倍視野)

免疫染色ではIgG陽性細胞を認めた。

C : ISH (in situ hybridization) (200倍視野)

ISH（in situ hybridization）でк monotypeを認めた。

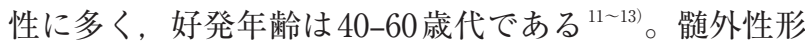

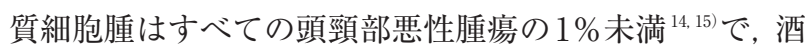
井らは，鼻副鼻胿悪性腫瘍 908 例の検討において髄外 性形質細胞腫は 1 例のみであったと報告している ${ }^{16)}$ 。ま た，䯣外性形質細胞腫は形質細胞腫瘍の約 $4 \%^{2,6)}$ と少な 

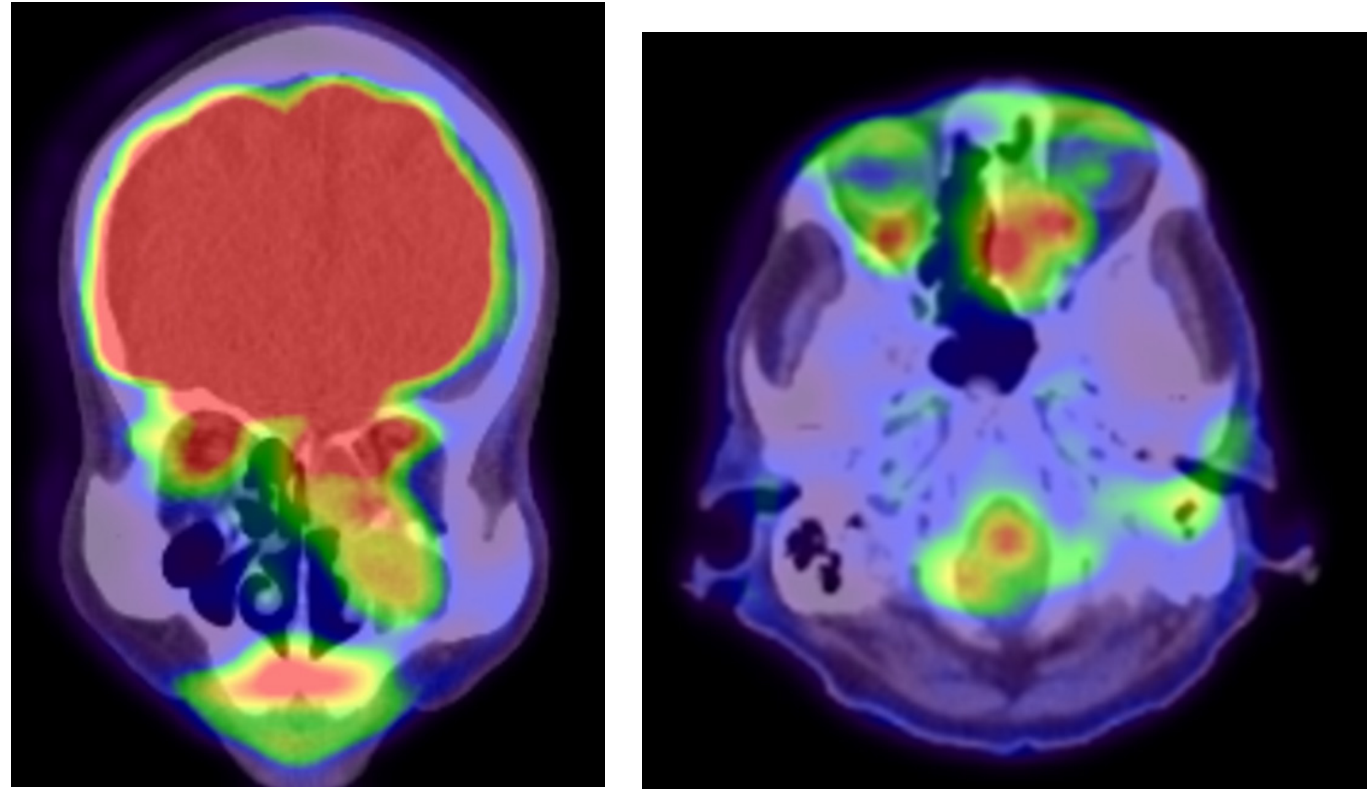

図5 FDG-PET

FDG-PETでは，左鼻副鼻腔内にFDG集積（SUVmax 10.74）を認めたが，頚部リンパ節転移や遠隔転移は認めな かった。
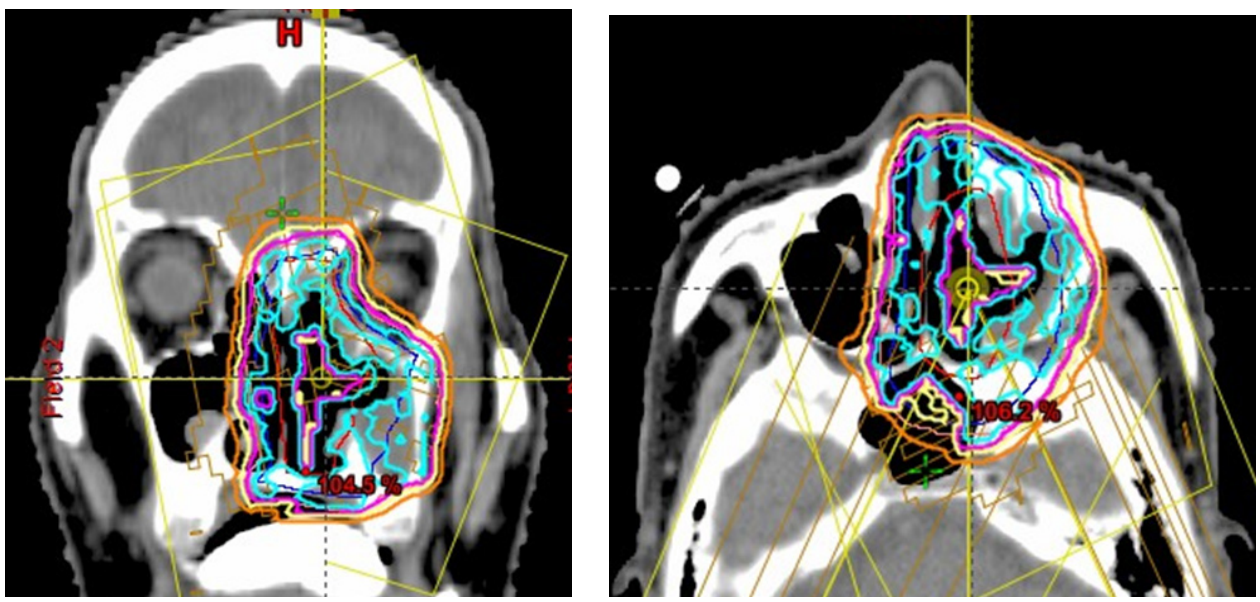

図6 IMRT（強度変調放射線治療）の等線量曲線

IMRT (強度変調放射線治療) で術後照射 (2 Gy/fr, 23 fr, total $46 \mathrm{~Gy})$ を施行した。

く，そのうちの約 70〜 80\%が頭頸部領域に発生するとさ れる ${ }^{1,2,6 ~ 9)}$ 。頭頸部領域での発生頻度は鼻副鼻腔原発が40 〜 50\%と最多で，上咽頭・中咽頭原発がそれぞれ約 20\%， 喉頭原発が約 $10 \%$ といわれている ${ }^{17)}$ 。そのため，耳鼻咽 喉科医は鼻副鼻腔腫瘍の鑑別疾患として, 髄外性形質細 胞腫を念頭に置く必要があると思われる ${ }^{18)}$ 。頭頸部・上 気道領域に好発する原因として，この部位はウイルスや 吸入された刺激物などの慢性的な外的抗原刺激を受けや すく ${ }^{19)}$ ，上気道粘膜下に広く分布した形質細胞に異常が 生じやすいことが報告されている ${ }^{20)}$ 。

臨床症状としては，腫瘍の発生部位により鼻閉，耳閉 感, 咽頭違和感, 後鼻漏, 鼻出血, 嗄声 ${ }^{21 ~ 24) な と ゙ か ゙ み ら ~}$
れる。多発性骨髄腫または骨の形質細胞腫を除外するに は，血清及び尿中のM蛋白や尿中のBence-Jones蛋白の 測定，骨髄生検を施行し ${ }^{25,26)}$ ，高カルシウム血症・腎不 全・貧血の存在を除外する必要がある ${ }^{27)}$ 。確定診断には 病理組織検査が必要である ${ }^{28)}$ 。形質細胞の腫瘍性増殖 と, 免疫組織学検査などにより腫瘍細胞内で産生される 単クローン性免疫グロブリンの証明が重要となる ${ }^{29)}$ 。穿 刺吸引細胞診は，免疫組織学検査に十分な材料が得られ ないため適切ではない ${ }^{30)}$ 。本症例では初診時に腫瘤を生 検したところ，腫瘍性病変はなく炎症性変化の疑いとの 結果であった。鼻副鼻腔腫痬では腫瘍により副鼻腔が閉 塞され，2次的に副鼻腔炎を生じて鼻茸が出現する場合 
が報告されている ${ }^{311}$ 。本症例では腫瘍ではない部位より 生検していた可能性がある。画像検查において髄外性形 質細胞腫に特徵的な所見はないとされている ${ }^{29} か ゙ ，$ 生検 を施行する前に可能であれば造影剂を用いた画像評価を 行い ${ }^{32}$, 造影効果や骨欠損部の有無を参考に腫瘍所見を十 分に確認し的確な部位から生検を施行する必要がある33) また, 腫瘍産生免疫グロブリンの割合は, IgG型が $55 \%$, IgA型が $22 \%$, Light chainのみが $18 \%$ ，非分泌型が1\% で ${ }^{34)}$ ， 型は $70 \% ， \lambda$ 型は $20 \%$ とされている ${ }^{35)}$ 。本症例で はIgG-型の診断となった。

髄外性形質細胞腫は症例が少ないこともあり，標準治 療は確立されていない ${ }^{36}$ が，放射線感受性が高いことが 知られている ${ }^{28)}$ 。そのため治療としては, 放射線単独療 法, または放射線療法と手術療法の併用が主体となって いる ${ }^{17.18)}$ 。頭頸部鹃道外性形質細胞腫の報告において，手 術療法と放射線療法の併用群は放射線療法単独群と比較 して生存期間の中央值が有意に良好な成績であったとい う報告 ${ }^{17}$, 併用群は手術療法単独群と比較して再発率が

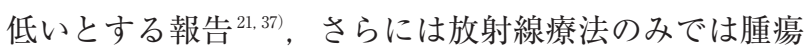
が残存することもあるため切除可能であれば外科的療法 を先行させ術後照射を行うべきという報告がある ${ }^{38)}$ 。頭 頸部髄外性形質細胞腫は安全域をつけた切除が困難な鼻 副鼻腔に好発するため, 手術療法単独での制御が困難と 推察されている ${ }^{39}$ 。完全な外科的切除が疑わしいまたは 不可能である場合は手術療法と放射線療法の併用療法が 推奨される ${ }^{17}$ 。英国のガイドラインでは, 照射線量は腫 瘍が $5 \mathrm{~cm}$ 未満なら $40 \mathrm{~Gy}(20 \mathrm{fr}), 5 \mathrm{~cm}$ 以上なら $50 \mathrm{~Gy}$ (25 fr) が適当で, 不完全切除例において術後放射線治 療を検討するべきとされている40。化学療法については, いまだ統一された見解が得られていないが，切除不能例 や遠隔転移を伴った進展例，多発例や再発例においては 多発性骨髄腫に準じた化学療法が推奨されている ${ }^{41,42}$ 。 また，放射線療法による初期治療後の補助化学療法に関 しては，多発性骨髄腫への進展抑制効果などの有用性は 示されて扔らず，逆に二次性白血病などのリスクが高ま ることが懸念されている ${ }^{43)}$ 。本症例では，左内視鏡下鼻 副鼻垫手術で可及的に腫瘍を切除した。腫瘍は肉眼的に は完全摘出できたが，十分な安全域をつけた切除ができ なかったため，術後放射線療法を行う方針となった。

髄外性形質細胞腫の頭頸部領域での 5 年生存率は約 $70 \%^{14.44)}, 10$ 年生存率は約 $50 \%{ }^{2.14)}$ とされる。治療後の局 所再発率が $30 \sim 40 \%$ 程度 ${ }^{21,45}$ と高く, 遠隔転移を起こ す確率は $30 \%$ 未満と報告されており ${ }^{46)}$ ，また数年以上経 過した後に多発性骨髄腫へ移行する症例が15～30\%とい

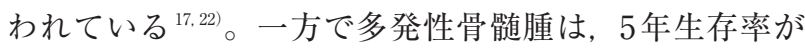

$10 \%$ 程度, 平均生存期間が約 1 2 年とされ，きわめて予 後不良である ${ }^{44)}$ 。多発性骨髄腫への移行例や局所再発例 は予後不良とされ ${ }^{18)}$, 特に多発性骨髄腫への進展が予後 を決めるとされている ${ }^{47}$ 。予後良好因子として，若年者 および腫瘍径 $5 \mathrm{~cm}$ 未満であることがいわれており ${ }^{48}$ ，ま た，多発性骨髄腫への進展を示唆する因子として，診断 時の腫瘍の大きさや蛋白分画での M蛋白の存在等が挙げ られている ${ }^{49}$ 。10年以上経過した後に多発性骨髄腫に移 行した症例も報告されている ${ }^{50}$ 。経過観察にあたり，骨 髄腫の病変検出には骨シンチグラフィーより FDG-PET が有用とされ ${ }^{25}$ ，FDG-PETの感度は $85 \%$ ，特異度 $92 \%$ と報告されている ${ }^{51.52)}$ 。本症例では，83歳と高齢であっ たが腫瘍径は $5 \mathrm{~cm}$ 未満であった。手術と放射線治療終了 後, 2 年半が経過しているが, 現時点では血液検査・尿 検査でM蛋白の発現は認めず多発性骨髄腫を示唆する 所見は認めてない。また, FDG-PETでも局所再発や遠 隔転移なく経過している。今後も血液検査・尿検查や FDG-PETなどを定期的に行い, 多発性骨髄腫への移行に 注意しながら長期間にわたり厳重な経過観察する必要が ある。

\section{まとめ}

1. 左鼻出血・左鼻閉を主訴とした，鼻副鼻脉内髄外性 形質細胞腫の 1 例を経験した。

2. 髄外性形質細胞腫は, 頭頸部領域に好発することが 知られており，まれな疾患であるが耳鼻咽喉科医とし て念頭に置き鑑別疾患として考虑する必要があると 思われる。

3. 形質細胞腫は放射線に高感受性である。本症例では, 手術で十分な安全域をつけた切除ができなかったた め, 術後放射線療法を施行した。

4. 髄外性形質細胞腫は数年以上経過した後にも多発性骨 髄腫へ移行する可能性が報告されており, 局所再発, 遠隔転移の有無も含めて, 長期にわたり厳重な経過観 察が必要と思われる。

本論文での要旨は, 平成 30 年 9 月の第 57 回日本鼻科学 会（旭川）で報告した。

\section{参考文献}

1）石川梧郎, 秋吉正豊：口腔病理学II. 改訂版. 永末 書店, 京都；1982: pp.662-665.

2) Wiltshalaw E: The natural history of extramedullary plasmacytoma and its relation to solitary myeloma of bone and myelomatosis. Medicine 1976; 55: 217-238. 
3) Megat Shiraz MAR, Jong YH, Primuharsa Putra SHA: Extramedullary plasmacytoma in the maxillary sinus. Singapore Med J 2008; 49: 310-311.

4) Batsakis JG, Medeiros JL, Luna MA, et al: Plasma cell dyscrasias and the head and neck. Ann Diagn Pathol 2002; 6: 129-140.

5) McKenna RW, Kyle RA, Kuehl WM, et al: Plasma cell neoplasms. Swerdlow SH, Campo E, Harris NL, et al: World Health Organization Classification Tumours of Haematopoietic and lymphoid Tissues, revised 4th edition, vol 2, IARC Press, Lyon, 2017; pp.241-258.

6) Fresen O: Extramedullary plasmacytomas. Nippon Ketsueki Gakkai Zasshi 1964; 27: 575-579.

7) Knowling MA, Harwood AR, Bergsagel DE: Comparison of extramedullary plasmacytomas with solitary and multiple plasma cell tumors of bone. J Clin Oncol 1983; 1: 255-262.

8) Galieni P, Cavo M, Pulsoni A, et al: Clinical outcome of extramedullary plasmacytoma. Haematologica 2000; 85: 47-51.

9) Tesei F, Caliceti U, Sorrenti G, et al: Extramedullary piasmocytoma (EMP) of the head and neck: A series of 22 cases. Acta Otorhinolaryngol Ital 1995; 13: 437-442.

10) Rajkumar SV, Dimopoulos MA, Palumbo A, et al: International Myeloma Working Group updated criteria for the diagnosis of multiple myeloma. Lancet Oncol 2014; 15: 538-548.

11）中川隆之, 恵田敏信, 高島忠義, 他：鼻中隔原発髄 外形質細胞腫例。耳鼻臨床 1996; 89: 443-447.

12) Soutar R, Lucraft H, Jackson G, et al: Working Group of the UK Myeloma Forum; British Committee for Standards in Haematology; British Society for Haematology: Guidelines on the diagnosis and management of solitary plasmacytorna of bone and solitary extramedullary plasmacytorna. Clin Oncol 2003; 16: 405-413.

13）松永信也，前山拓夫，島 哲也：頭頸部領域に原発 した髄外性形質細胞腫の3 症例。耳鼻臨床 1987; 80: $257-265$

14) Webb HE, Harrison EG, Masson JK, et al: Solitary extramedullary myeloma (plasmacytoma) of the upper part of the respiratory tract and oropharynx. Cancer 1962; 15: 1142-1155.
15) Rodriguez-de-Velasquez A, Weber AL, Montgomery W: Extramedullary laryngeal plasmacytoma. Ann Otol Rhinol Laryngol 1996; 105: 483-486.

16）酒井俊一，尾崎正義，池田 寛，他：鼻・副鼻腔悪 性腫瘍 908例の観察。耳鼻と臨床 1975; 21: 859-884.

17) Alexiou C, Kau RJ, Dietzfelbinger H, et al: Extramedullary plasmacytoma: tumor occurrence and therapeutic concepts. Cancer 1999; 85: 2305-2314.

18）森 智昭, 江川峻哉, 小野智裕, 他：鼻腔内に発生 した髄外性形質細胞腫の1例. 耳展 2009; 52: 456-460.

19) International Myeloma Working Group: Criteria for the classification of monoclonal gammopathies, multiple myeloma and related disorders: a report of the International Myeloma Working Group. Br J Haematol 2003; 121: 749-757.

20）志藤文明, 森本賢治, 三部重雄, 他：咽頭に原発し たIgA-K型髄外性形質細胞腫（第1報）臨床的および 免疫学的検討とその文献的考察. 日耳鼻 1981；84: 836-847.

21）脇坂尚弘，長山郁生，古川 仞，他：上咽頭に原発 した髄外性形質細胞腫の 1 症例。耳鼻展望 1997; 40: 200-204.

22) Kapadia SB, Desai U, Cheng VS: Extramedullary plasmacytoma of the head and neck. Medicine 1982; 61: 317-329.

23) Medina E, Rao Y, Levitt SH: Solitary extramedullary plasmacytoma of the upper respiratory and digestive tracts. Cancer 1980; 45: 2893-2896.

24) Miller FR, Lavertu P, Wanamaker JR, et al: Plasmacytomas of the head and neck. Otolaryngol Head Neck Surg 1998; 119: 614-618.

25) Meis JM, Butler JJ, Osborne BM, et al: Solitary plasmacytomas of bone and extramedullary plasmacytomas. A clinicopathologic and immunohistochemical study. Cancer 1987; 59: 1475-1485.

26) Sulzner SE, Amdur RJ, Weider DJ: Extramedullary plasmacytoma of the head and neck. Am J Otolaryngol 1998; 19: 203-208.

27) Hoon S, Zoon Y, Hee E, et al: Endoscopic endonasal transsphenoidal resection of solitary extramedullary plasmacytoma in the sphenoid sinus with destruction of Skull base. J Korean Neurosurg Soc 2009; 46: $156-160$.

28) Sodhi KS, Khandelwal N, Virmani V, et al: Solitary extramedullary plasmacytoma of the nasal tract: 
An unusual cause of epistaxis. Ear Nose Throat J 2013; 92: 51-54.

29）柏野香里：上咽頭に発生した䯣外性形質細胞腫例。 耳鼻臨床 2008; 101: 445-452.

30) Shahrizal TA, Prepageran N, Rahmat O, et al: Isolated extramedullary plasmacytoma of the middle turbinate. Ear Nose Throat J 2009; 88: 786-789.

31）馬場信太郎，熊谷 譲，佐々木拓雄，他：上咽頭に 発生した髄外性形質細胞腫の 1 例。耳喉頭頸 2006; 78: 769-772

32）花澤豊行：鼻副鼻腔内の腫瘍性病変への対応 生検 に抢ける留意点. 日鼻誌 2016; 55: 105-108.

33）槙 大輔, 大上研二, 酒井昭博, 他：口蓋扁桃に発 生した髄外性形質細胞腫の1例。耳喉頭頸 2011; 83: 360-363.

34) Brunning RD: Plasma cell dyscrasias and related disorders. In: Tumors of the bone marrow, Atlas of Tumor Pathology, Armed Forces Institute of Pathology, Washington; 1993: pp.323-367.

35) Boo K, S Cheng: A morphological and immunohistochemical study of plasma cell proliferative lesions. Malaysian J Pathl 1992; 14: 45-48.

36) Sasaki R, Yasuda K, Abe E, et al: Multi-institutional analysis of solitary extramedullary plasmacytoma of the head and neck treated with curative radiotherapy. Int J Radiat Oncol Biol Phys 2012; 82: $626-634$

37）吉崎智一, 脇坂尚宏, 嘉藤秀章, 他：上咽頭の珍し い悪性腫瘍 上咽頭原発䯣外性形質細胞腫. JOHNS 1999; 15: 1307-1309.

38）韓 相善, 北村溥之, 高北晋一, 他：頭頸部領域 に多発した髄外性形質細胞腫例。耳鼻臨床 1996; 89: 1377-1381.

39）末吉慎太郎，力丸文秀，檜垣雄一郎，他：耳下腺原 発髄外性形質細胞腫例. 耳鼻臨床 2016; 109: 493-499.

40) Soutar R, Lucraft H, Jackson G, et al: Guidelines on the diagnosis and management of solitary plasmacytoma of bone and solitary extramedullary plasmacytoma. Br J Haematol 2004; 124: 717-726.

41) Ooi GC, Chim JC, Au WY, et al: Radiologic manifestations of primary solitary extramedullary and multiple solitary plasmacytomas. AJR Am J Roentgenol 2006; 186: 821-827.

42）本間 朝, 朝倉光司, 川口竜一, 他 : 右口蓋扁桃に 発生した髄外性形質細胞腫の1例。室蘭病医誌 2002; 27: 51-54.

43）一般社団法人 日本血液学会 : 造血器腫瘍診療ガイ ドライン 2018年版. 金原書店, 京都；2018: p.370.

44）片橋立秋, 高木敏之, 島田文之, 他：鼻腔ならびに 上咽頭に発声した形質細胞腫の4例．癌の臨床 1994; 40: $1251-1258$.

45）西屋圭子, 海山智九，奥野敬一郎：顎下部に原発し た髄外性形質細胞腫の 1 症例。頭頸部外 2007；17: $161-165$.

46）大江正士郎，八木俊和，安東勝宏，他：大腸原発䯣 外性形質細胞腫の1例. 日消外会誌 2014; 47: 637-643.

47) Dores GM, Landgren O, McGlynn KA, et al: Plasmacytoma of bone, extramedullary plasmacytoma, and multiple myeloma: incidence and survival in the United States, 1992-2004. Br J Haematol 2009; 144: 86-94.

48) Nanni C, Rubello D, Zamagni E, et al: $18 \mathrm{~F}-\mathrm{FDG}$ $\mathrm{PET} / \mathrm{CT}$ in myeloma with presumed solitary plasmocytoma of bone. In Vivo 2008; 22: 513-517.

49) Holland J, Trenkner DA, Wasserman TH, et al: Plasmacytoma. Treatment results and conversion to myeloma. Cancer 1992; 69: 1513-1517.

50) Corwin J, Lindberg RD: Solitary Plasmacytoma of Bone vs. Extramedullary Plasmacytoma and their Relationship to Multiple Myeloma. Cancer 1979; 43 1007-1013.

51) Dimopoulos M, Terpos E, Comenzo RL, et al: International myeloma working group consensus statement and guidelines regarding the current role of imaging techniques in the diagnosis and monitoring of multiple Myeloma. Leukemia 2009; 23: $1545-1556$.

52) Bredella MA, Steinbach L, Caputo G, et al: Value of FDG PET in the assessment of patients with multiple myeloma. AJR Am J Roentgenol 2005; 184: 1199-1204. 